\title{
Intestinal protozoa and helminths among Terena Indians in the State of Mato Grosso do Sul: high prevalence of Blastocystis bominis
}

\author{
Protozoários e helmintos intestinais entre índios Terena \\ do Estado do Mato Grosso do Sul: alta prevalência de Blastocystis bominis
}

\author{
José Ivan Albuquerque Aguiar ${ }^{1}$, Alessandra Queiroga Gonçalves², Fernando Campos Sodré3 \\ Severino dos Ramos Pereira², Márcio Neves Bóia², Elba Regina Sampaio de Lemos ${ }^{4}$ \\ and Roberto Ruhman Daher ${ }^{5 \dagger}$
}

\begin{abstract}
A parasitological survey was carried out among Terena Indians living in the Tereré settlement in the municipality of Sidrolândia, State of Mato Grosso do Sul, Brazil. Single samples of feces from 313 Indians were processed by means of the spontaneous sedimentation method. In the population studied, $73.5 \%$ were infected with at least one intestinal parasite or commensal. Protozoa predominated. Blastocystis hominis (40.9\%), Entamoeba coli (33.2\%) and Entamoeba histolyticaEntamoeba dispar (31.6\%) were the most common. Bivariate analysis showed that females were generally more infected and presented higher rates of infection by Entamoeba histolytica/Entamoeba dispar and Entamoeba coli. Males were more infected by hookworms and Strongyloides stercoralis than females. The precarious sanitary conditions of the Tereré settlement are probably a contributory factor towards the high prevalence of intestinal protozoa.
\end{abstract}

Key-words: Blastocystis hominis. Intestinal parasites. Commensals. Indians. Brazil.

\section{RESUMO}

Um inquérito parasitológico foi realizado em índios Terena da aldeia Tereré, do município de Sidrolândia, Estado do Mato Grosso do Sul, Brasil. Amostras únicas de fezes de 313 indios foram processadas pelo método de sedimentação espontânea. Na população estudada, 73.5\% estavam infectados por pelo menos um parasita ou comensal intestinal. Os protozoários predominaram. Blastocystis hominis (40.9\%), Entamoeba coli (33.2\%) e Entamoeba histolytica/Entamoeba dispar (31.6\%) foram os mais comuns. A análise bivariada demonstrou que as mulheres estavam mais infectadas no geral e apresentavam maior taxa de infecção para Entamoeba histolytica/Entamoeba dispar $e$ Entamoeba coli. Os homens estavam mais infectados por ancilostomídeos e Strongyloides stercoralis que as mulheres. As precárias condições sanitárias da aldeia Tereré são provavelmente um fator contribuinte para a alta prevalência de protozoários.

Palavras-chaves: Blastocystis hominis. Parasitas intestinais. Comensais. Índios. Brasil.

Studies on the health of indigenous people of the Terena ethnic group have been distinguished by focusing on the fields of nutrition, autoimmune diseases, degenerative diseases and alcoholism $^{12341218222529}$. However, data on the prevalence of intestinal protozoa and helminths among this ethnic group are very scarce in the literature.

In 1972, Perez, Artigas and Ponte ${ }^{24}$ conducted a parasitological survey among 415 individuals who were attended at health centers in the State of São Paulo that serve Guarani, Kaingangue and
Terena Indians. However, these authors did not discriminate their parasitological results according to ethnic group, which made it impossible to analyze infection among the Terena separately. Subsequently, Alves ${ }^{3}$ estimated the prevalence of intestinal protozoa and helminths among 244 Terena children from the Limão Verde community, which is located in the municipality of Aquidauana (State of Mato Grosso do Sul). This study was the first and until now the only record of intestinal parasites and commensals that was exclusively focused on populations of this ethic group.

\footnotetext{
$\dagger$ in memorian Tel: $55212280-3740$

e-mail: queiroga@ioc.fiocruz.br

Recebido em: 26/06/07

Aceito em: 15/10/2007
}

1. Departamento de Medicina Interna, Universidade Federal do Mato Grosso do Sul, Campo Grande, MS. 2. Laboratório de Doenças Parasitárias, Instituto Oswaldo Cruz, Fundação Oswaldo Cruz, Rio de Janeiro, RJ. 3. Departamento de Patologia, Faculdade de Medicina, Universidade Federal Fluminense, Niterói, RJ. 4. Laboratório de Hantaviroses e Rickettsioses, nstituto Oswaldo Cruz, Fundação Oswaldo Cruz, Rio de Janeiro, RJ. 5. Instituto de Patologia Tropical e Saúde Pública, Universidade Federal de Goiás, Goiânia, GO. Address to: Dra. Alessandra Queiroga Gonçalves. Laboratório de Doenças Parasitárias/FIOCRUZ. Av. Brasil 4365, Manguinhos, 21045-900 Rio de Janeiro, RJ. 
Table 1 - Prevalence rates of protozoa and helminths among Terena Indians from Sidrolândia, State of Mato Grosso do Sul, according to age groups, sex and species.

\begin{tabular}{|c|c|c|c|c|c|c|c|c|c|c|c|c|}
\hline \multirow{2}{*}{$\begin{array}{l}\text { Age } \\
\text { groups } \\
\text { (years) }\end{array}$} & \multicolumn{12}{|c|}{ Prevalence rates (\%) } \\
\hline & number & $\mathrm{Bh}$ & Ec & Eh/Ed & En & $\mathrm{Hn}$ & $\mathrm{Gl}$ & $\mathrm{Hk}$ & Ss & $\mathrm{Ib}$ & $\mathrm{Al}$ & $\mathrm{Ev}$ \\
\hline$\leq 4$ & 59 & 27.1 & 5.1 & 10.2 & 5.1 & 3.4 & 18.6 & - & - & - & - & - \\
\hline $5-9$ & 41 & 46.3 & 63.4 & 48.8 & 29.3 & 29.3 & 14.6 & 2.4 & 7.3 & 2.4 & 2.4 & - \\
\hline $10-19$ & 85 & 42.4 & 37.6 & 37.6 & 23.5 & 11.8 & 4.7 & 15.3 & 2.4 & 2.4 & 1.2 & 1.2 \\
\hline $20-39$ & 79 & 45.6 & 27.8 & 25.3 & 22.8 & 2.5 & 1.3 & 8.9 & 6.3 & 5.1 & - & - \\
\hline $40-59$ & 34 & 38.2 & 50.0 & 52.9 & 8.8 & - & 5.9 & 2.9 & 2.9 & 2.9 & - & - \\
\hline$\geq 60$ & 15 & 53.3 & 26.7 & 20.0 & 26.7 & - & 6.7 & - & 6.7 & - & - & - \\
\hline Total & 313 & 40.9 & 33.2 & 31.6 & 19.2 & 8.3 & 8.0 & 7.0 & 3.8 & 2.6 & 0.6 & 0.3 \\
\hline Males & 167 & 35.9 & 26.9 & 26.3 & 15.6 & 7.8 & 6.6 & $10.2^{\mathrm{c}}$ & $6.0^{\mathrm{d}}$ & 2.4 & - & 0.6 \\
\hline Females & 146 & 46.6 & $40.4^{\mathrm{a}}$ & $37.7^{\mathrm{b}}$ & 22.6 & 8.9 & 9.6 & 3.4 & 1.4 & 2.7 & 1.4 & - \\
\hline
\end{tabular}

Bh: Blastocystis hominis, Ec: Entamoeba coli, Eh/Ed: Entamoeba histolytica/Entamoeba dispar, En: Endolimax nana, Hn: Hymenolepis nana, Gl: Giardia lamblia, Hk: Hookworms, Ss: Strongyloides stercoralis, Ib: Iodamoeba butschlii, Al: Ascaris lumbricoides, Ev: Enterobius vermicularis.

$\mathrm{a}: \mathrm{p}=0.012, \mathrm{~b}: \mathrm{p}=0.032, \mathrm{c}: \mathrm{p}=0.020 ; \mathrm{d}: \mathrm{p}=0.034$

The present study provides data on the prevalence of intestinal protozoa and helminths among Terena Indians in the municipality of Sidrolândia, Mato Grosso do Sul.

\section{MATERIAL AND METHODS}

Population studied. With a population estimated as 16,000 people in 2001, the Terena Indians that live in the State of Mato Grosso do Sul are scattered across a few municipalities: Miranda, Aquidauana, Anastácio, Dois Irmãos do Buriti, Sidrolândia, Nioaque and Rochedo. The territory of their settlements was occupied in the eighteenth century, when they migrated to Mato Grosso do Sul from the Chaco region of Paraguay ${ }^{16}$. This study was conducted in the Tereré settlement, which is located on the outskirts of the urban area of the municipality of Sidrolândia, $70 \mathrm{~km}$ from Campo Grande.

Survey. A parasitological survey was carried out between November 1998 and February 1999, among the whole population of the Tereré settlement. Single samples of feces from the 313 Indians living in this settlement were preserved in MIF solution (merthiolate-iodine-formaldehyde) and were processed by means of the spontaneous sedimentation method ${ }^{19}$. The data were analyzed using the STATA software, version 9.0, and comparisons between groups were made by means of bivariate analysis using the chi-square test $\left(\mathrm{X}^{2}\right)$, taking statistical significance at the level of $5 \%$. The work was carried out with the help of health agents for the welfare of the indigenous population. The study was granted prior approval by the Research Ethics Committee of the Federal University of Mato Grosso do Sul. All the participants who needed treatment received it after the survey had been accomplished.

\section{RESULTS}

The results showed that $73.5 \%$ of the population was infected with at least one species. Protozoa predominated and were identified in $66.5 \%(208 / 313)$ of the subjects, while helminths were present in $18.5 \%(58 / 313)$. Table 1 summarizes the findings from the parasitological survey. Blastocystis bominis (40.9\%), Entamoeba coli (33.2\%) and Entamoeba histolytical Entamoeba dispar (31.6\%) were the most common protozoa. Among the helminths, Hymenolepis nana and hookworms were found in $8.3 \%$ and $7 \%$ of the samples, respectively. Only two cases of Ascaris lumbricoides were found.

The chi-square test showed that females were generally more infected, presented higher rates of infection by protozoa than did males ( $\mathrm{p}=0.001)$ and higher rates by Entamoeba histolytical Entamoeba dispar and Entamoeba coli $(\mathrm{p}=0.032$ and $\mathrm{p}=0.012$, respectively). Although generally less infected, males presented higher infection rates in relation to hookworms and Strongyloides stercoralis $(\mathrm{p}=0.020$ and $\mathrm{p}=0.034$, respectively).

The level of infection by Blastocystis hominis was lower among children $\leq 4$ years of age and equal among the individuals in all the other age groups. Entamoeba histolytica/Entamoeba dispar was most prevalent among adults aged 40-59 years and also present in almost half (48.8\%) of the children aged 5-9 years. Giardia lamblia predominated among children $\leq 4$ years old.

With regard to infection by two or more protozoa and/or helminths, $24.3 \%$ of the individuals had only one parasite or commensal, $26.2 \%$ had two, $15 \%$ had three, $6.1 \%$ had four and $1.9 \%$ had five. There was no difference in the level of infection by two or more protozoa and/or helminths between the sexes $(p=0.577)$, but there were differences between age groups. Infection by two or more protozoa and/or helminths was more frequent among children aged 5-9 years, and this group was statistically similar to the groups in the age ranges of 10-19 and 40-59 years.

\section{DISCUSSION}

In the present survey, Indians presented high rates of infection. Our results resemble those obtained by Alves ${ }^{3}$, in which $70.1 \%$ of the Terena children analyzed presented some parasite or 
commensal in their feces. There was also low prevalence of helminths like Ascaris lumbricoides (1.6\%) and hookworms (4.1\%), and absence of Trichuris trichiura. Giardia lamblia had the highest prevalence (30.2\%), followed by the commensal species Entamoeba coli (20.9\%). Among the other protozoa and helminths, the frequencies obtained were: Endolimax nana, 15.9\%; Iodamoeba butschlii, 11.4\%; Hymenolepis nana, 10.6\%; Strongyloides stercoralis, 3.3\%; and Taenia sp, $0.4 \%{ }^{3}$. Infections by Entamoeba histolytica/Entamoeba dispar and Blastocystis bominis were not reported.

A high (31.6\%) proportion of the population studied presented infection with Entamoeba histolytica/Entamoeba dispar. Studies among Brazilian indigenous populations have demonstrated that infection with Entamoeba histolytica/Entamoeba dispar is often the most prevalent of the infections with protozoa ${ }^{81415172021}$. Because of the possibility that the individuals infected might present symptomatic conditions, caused by the species Entamoeba bistolytica, a better investigation should be conducted in the Tereré settlement, using specific diagnostic tests for differentiating between Entamoeba histolytica and Entamoeba dispar.

The parasitological profile found among the Terena Indians is also close to some reports on the Brazilian indigenous population in the literature, in which helminths presented low prevalence ${ }^{813}$. These populations had all undergone some type of therapeutic intervention, which was possibly one of the factors contributing towards the observed low prevalence of helminths. In the Tereré settlement, treatments with anti-helminth agents had occasionally been carried out over the years preceding the collection of the material for this study, which was done by health agents for indigenous communities working for the municipal health department. Although no periodic parasitological surveys had been carried out to prove the effectiveness of treatments administered previously among the Terena, several studies have emphasized the importance of using mass medication for controlling intestinal parasitosis $^{78132627}$.

Another important finding was the high prevalence of Blastocystis hominis, which was observed in practically all age groups and was the commonest species in the Tereré settlement. This protozoan, whose pathogenicity is still a matter for debate ${ }^{59}$, has rarely been reported among Brazilian indigenous populations. The possible explanations for this are failure by analysts to recognize it under the microscope, use of incorrect techniques or failure to attribute importance to the forms encountered ${ }^{510}$. In one rare record, Palhano-Silva ${ }^{23}$ reported low prevalence of Blastocystis bominis (7.9\%) among Suruí Indians in the State of Rondônia. In the Terena population, the high prevalence of Blastocystis hominis coincides with the high prevalence also observed for other protozoa. At present, there is no specific explanation for this finding other than the possibility of high transmission through water. The spontaneous sedimentation method, although not the most sensitive for diagnosing certain species such as Strongyloides stercoralis, has demonstrated adequate results for Blastocystis hominis when the sample was previously fixed in formol-based conserving media at $10 \%$ concentration $^{628}$. Therefore, we believe that the results obtained here satisfactorily reflect the frequency of this protozoan among the population, even though this did not occur for Strongyloides stercoralis.

Infection by two or more protozoa and/or helminths was very common, and affected almost half (49.2\%) of the population. Our study also demonstrated a difference between the sexes, such that women were more infected in general. This could indicate greater exposure to waterborne transmission among the women, caused by the particular habits of the women in this community, which were not, however, covered in this study. The men presented greater infection by hookworms and Strongyloides stercoralis. This was also observed (for hookworms) by Miranda et al ${ }^{20}$, among indigenous men of the Tembé ethnic group. Although some studies have suggested that men have greater contact with infecting forms that are contained in the soil, new studies relating age groups to activity and sex should be conducted to clarify this question better ${ }^{11}$.

We can highlight the precarious sanitary conditions in which the Terena Indians live as a contributory factor towards the high general prevalence observed in the Tereré settlement. These people get their water supply from an artesian well and most of them use rudimentary cesspit systems. The high degree of soil and water contamination, which is characteristic of places with a low level of sanitation, is probably responsible for the health conditions reported.

\section{ACKNOWLEDGEMENTS}

To health agents for indigenous communities from the municipal health department of Sidrolândia, State of Mato Grosso do Sul, for logistic support.

\section{REFERENCES}

1. Aguiar JIA, Souza JA, Sganzerla A, Mangolin O, Maia T, Lopes K, Stella S, Cohrs F, Aguiar E, Uehara S, Ferreira CMH. Enfermidades degenerativas entre os Terena de Mato Grosso do Sul. Uma abordagem de aspectos ligados ao diabetes tipo II e fatores correlacionados. In: Anais do Seminário sobre alcoolismo e DST/AIDS entre os povos indígenas da macrorregião sul, sudeste e Mato Grosso do Sul. Série Seminários e Congressos número 4. Ministério da Saúde. p. 77-82, 2001.

2. Aguiar JIA, Souza JA. Prevalência do Alcoolismo na População Indígena da Nação Terena do Complexo Sidrolândia-Colônia Dois Irmãos do Buriti. In: Anais da I Oficina Macro Regional de Estratégia, Prevenção e Controle das DST/AIDS para as Populações Indígenas das Regiões Sul, Sudeste e do Mato Grosso do Sul. Ministério da Saúde. Londrina, p. 117-124, 1997.

3. Alves GMS. Estado Nutricional, absorção e tolerância à lactose e sobrecrescimento bacteriano no intestino delgado de crianças índias Terenas - Mato Grosso do Sul, Brasil. Tese de Doutorado, Universidade Federal de São Paulo, São Paulo, SP, 1998.

4. Alves GMS, Morais MB, Fagundes-Neto U. Estado nutricional e teste do hidrogênio no ar expirado com lactose e lactulose em crianças indígenas Terena. Jornal de Pediatria 78:113-119, 2002.

5. Amato Neto V, Alarcon RSR, Gakiya E, Bezerra RC, Ferreira CS, Braz LM. Blastocistose: controvérsias e indefinições. Revista da Sociedade Brasileira de Medicina Tropical 36:515-517, 2003.

6. Amato Neto V, Alarcon RSR, Gakiya E, Ferreira CS, Bezerra RC, Santos AG. Elevada porcentagem de Blastocistose em escolares de São Paulo, SP. Revista da Sociedade Brasileira de Medicina Tropical 37:354-356, 2004. 
7. Boia MN, Carvalho-Costa FA, Sodre FC, Eyer-Silva WA, Lamas CC, Lyra MR, Pinto VLJR, Cantalice Filho JP, Oliveira AL, Carvalho LM, Gross JB, Sousa AL, Moraes TI, Bermudez-Aza EH, Martins EB, Coura JR. Mass treatment for intestinal helminthiasis control in an Amazonian endemic area in Brazil. Revista do Instituto de Medicina Tropical de São Paulo 48:189-195, 2006.

8. Coimbra Jr CE, Santos RV. Avaliação do estado nutricional num contexto de mudança sócio-econômica: o grupo indígena Suruí do estado de Rondônia, Brasil. Cadernos de Saúde Publica 7:538-562, 1991.

9. Devera R. Blastocystis hominis: 0 enigma continua. Revista da Sociedade Brasileira de Medicina Tropical 31:491-492, 1998.

10. Devera R. Blastocystis hominis: parasita intestinal pouco estudado no Brasil. Jornal Brasileiro de Medicina 76: 85-89, 1999.

11. Dórea RC, Salata E, Padovani CR, Anjos GL. Control of parasitic infections among school children in the peri-urban area of Botucatu, São Paulo, Brazil. Revista da Sociedade Brasileira de Medicina Tropical 29: 425-430, 1996.

12. Fávaro T, Ribas DLB, Zorzatto JR, Segall-Corrêa AM, Panigassi G. Segurança alimentar em famílias indígenas Terena, Mato Grosso do Sul, Brasil. Cadernos de Saúde Pública 23:785-793, 2007.

13. Ferrari JO, Ferreira MU, Aranha Camargo LM, Ferreira CS. Intestinal parasites among Karitiana Indians from Rondonia State, Brazil. Revista do Instituto de Medicina Tropical de Sao Paulo 34:223-225, 1992.

14. Fontbonne A, Freese-de-Carvalho E, Acioli MD, de Sá G, Cesse EAP. Fatores de risco para poliparasitismo intestinal em uma comunidade indígena. Cadernos de Saúde Pública 17:367-373, 2001.

15. Genaro 0, Ferraroni JJ. Estudo sobre malaria e parasitoses intestinais em indígenas da tribo Nadeb-Maku, Estado do Amazonas, Brasil. Revista de Saúde Pública 18:162-169, 1984

16. Ladeira MEM. Língua e história: análise sociolingüística em um grupo Terena. Tese de Doutorado, Universidade de São Paulo, São Paulo, SP, 2001

17. Lawrence DN, Neel JV, Abadie SH, Moore LL, Adams LJ, Healy GR, Kagan IG. Epidemiologic studies among Amerindian populations of Amazonia. III. Intestinal parasitoses in newly contacted and acculturating villages. American Journal of Tropical Medicine and Hygiene 29: 530-537, 1980

18. Lima MG, Koifman S, Scapulatempo IL, Peixoto M, Naomi S, Amaral MC. Fatores de risco para câncer de mama em mulheres indígenas Terena de área rural, estado do Mato Grosso do Sul, Brasil. Cadernos de Saúde Publica 17:1537-1544, 2001.
19. Lutz A. O Schistosoma mansoni e a schistosomose segundo observações feitas no Brasil. Memórias do Instituto Oswaldo Cruz 11: 121-155, 1919

20. Miranda RA, Xavier FB, Menezes RC. Parasitismo intestinal em uma aldeia indígena Parakanã, sudeste do Estado do Pará, Brasil. Cadernos de Saúde Pública 14: 507-511, 1998.

21. Miranda RA, Xavier FB, Nascimento JRL, Menezes RC. Prevalência de parasitismo intestinal nas aldeias indígenas da tribo Tembé, Amazônia Oriental Brasileira. Revista da Sociedade Brasileira de Medicina Tropical 2: 389-393, 1999

22. Morais MB, Alves GM, Fagundes-Neto U. Nutritional status of Terena Indian children from Mato Grosso do Sul, Brazil: follow up of weight and height and current prevalence of anemia. Jornal de Pediatria 81:383-389, 2005.

23. Palhano-Silva CS. Parasitoses Intestinais entre os Índios Suruí, Região Amazônica, Brasil. Dissertação de Mestrado, Escola Nacional de Saúde Pública Sérgio Arouca, Fundação Oswaldo Cruz, Rio de Janeiro, RJ, 2006.

24. Perez MD, Artigas PT, Ponte GD. Levantamentos parasitológicos, visando em particular a esquistossomose mansônica, realizados em postos indígenas do Estado de São Paulo. Contribuição ao levantamento da carta planorbídica do Estado de São Paulo. Revista de Farmácia e Bioquímica da Universidade de São Paulo 10: 239-245, 1972.

25. Ribas DL, Sganzerla A, Zorzatto JR, Philippi ST. Nutrição e saúde infantil em uma comunidade indígena Terena, Mato Grosso do Sul, Brasil. Cadernos de Saúde Pública 17: 323-31, 2001

26. Santos RV, Coimbra Jr CEA, Flowers NM, Silva JP. Intestinal Parasitism in the Xavante Indians, Central Brazil. Revista do Instituto de Medicina Tropical de São Paulo 37: 145-148, 1995.

27. Santos RV, Coimbra Jr CEA, Ott AMT. Estudos epidemiológicos entre grupos indígenas de Rondônia. III. Parasitoses intestinais nas populações dos vales dos rios Guaporé e Mamoré. Cadernos de Saúde Pública 1: 467-477, 1985.

28. Velásquez V, Caldera R, Wong W, Cermeno G, Fuentes M, Blanco Y, Aponte M, Devera R. Elevada prevalência de blastocistose em pacientes do Centro de Saúde de Soledad, Estado Anzoátegui, Venezuela. Revista da Sociedade Brasileira de Medicina Tropical 38: 356-357, 2005

29. Warren SJ, Lin MS, Giudice GJ, Hoffmann RG, Hans-Filho G, Aoki V, Rivitti EA Santos V, Diaz LA. The prevalence of antibodies against desmoglein 1 in endemic pemphigus foliaceus in Brazil. Cooperative Group on Fogo Selvagem Research. The New England Journal of Medicine 343: 23-30, 2000. 